\title{
Parotitis in a pemphigus vulgaris patient with widespread oral lesions: a rare or underdiagnosed condition?
}

\section{Yaygın oral lezyonları olan bir pemfigus vulgaris hastasında parotit gelişmesi: nadir ya da gözden kaçan bir durum?}

\author{
Zuleyha Ozgen $^{1}$, Elif Comert Ozer ${ }^{1}[$, Dilek Seckin Gencosmanogluํ] \\ ${ }^{1}$ Dept of Dermatology, Marmara University School of Medicine, Istanbul, Turkey
}

\begin{abstract}
Parotitis is the inflammation of the parotid gland and frequently due to bacterial and viral infections, but mechanical obstruction of parotitis ductus, Sjogren's disease, other xerostomia etiologies, sarcoidosis, tuberculosis, oral ulcerations, and drugs can also cause parotitis though less frequently. Pemphigus vulgaris patients may theoretically be at an increased risk for parotitis and other salivary gland inflammations because of various reasons such as oral ulcers, poor oral intake, multiple drug use and other possible accompanying autoimmune diseases, however, such an association is reported rarely in literature. In this study, development of parotitis in a pemphigus vulgaris patient with widespread oral ulcers is presented and a possible association between parotitis and pemphigus is discussed.
\end{abstract}

Key words: parotitis, sialadenitis, pemphigus vulgaris, oral ulcer

O̊z

Parotit, parotis bezinin iltihaplanması olup, sıklıkla bakteriyel ve viral enfeksiyonlar nedeniyle, daha nadir olarak da parotis kanalının mekanik tıkanması, oral alımın bozulması, Sjögren hastalı̆̆ı, diğer ağız kuruluğu nedenleri, sarkoidoz, tüberküloz, ağız içinde ülser gelişimi ve bazı ilaçlar ile gelişebilmektedir. Pemfigus vulgaris hastalarının ağız içi ülserleri, oral alımlarında bozulma, kullandıkları çoklu ilaçlar ve eşlik edebilecek diğer otoimmün hastalıklar gibi çeşitli nedenlerle parotit ve diğer tükürük bezi iltihaplanmaları açısından artmış riske sahip olabilecekleri teorik olarak beklenmesine karşın literatürde bildirilmiş birliktelik az sayıdadır. Burada, yaygın oral ülserleri olan bir pemfigus vulgaris hastasında parotit gelişimi sunulmakta, parotit ile pemfigus arasındaki olası ilişki tartışılmaktadır.

Anahtar kelimeler: parotit, tükrük bezi iltihabl, pemfigus vulgaris, oral ülser

Corresponding author: Elif Comert Ozer, Dept. of Dermatology Marmara University Fevzi Cakmak M. Mimar Sinan C. No:41 34899

Pendik, Istanbul, Turkey, Phone: +90 216 6570606, E-mail: elifcomertt@gmail.com

Received: 1 July 2020 Accepted: 15 February 2021

Conflicts of Interest: None

Funding: None

How to cite this article: Ozgen Z, Comert Ozer E, Seckin Gencosmanoglu D. Parotitis in a pemphigus vulgaris patient with widespread oral lesions: a rare or underdiagnosed condition? Mucosa 2021;4:23-26

(c) (i) () This work is licensed under a Creative Commons Attribution-NonCommercial 4.0 International License. 


\section{Introduction}

Parotitis and other salivary gland inflammations are usually caused by mechanical trauma and infections such as mumps- a well-known etiology- tuberculosis and Staphylococcus aureus and commensal bacteria infections. Hypersensitivity reactions, Sjogren's syndrome and other dry mouth causes, sarcoidosis, obstruction of the salivary gland ducts and its branches with stone, tumor and mucous plug, diseases leading to dehydration such as anorexia nervosa and gastrointestinal pathologies, granulomatosis with polyangiitis and organic phosphate poisoning are other rare etiological factors. ${ }^{1}$ Drugs have also been reported to cause parotitis. Although certain drugs such as chlormethiazole, methimazole, epinephrine, naproxen, antipsychotics and antidepressants, cytarabine, histamine receptor blockers, interferon alpha, methyldopa, antihypertensive agents and antibiotics are among these, there are sufficient evidence for direct causal association only with a small number of drugs, such as asparaginase, clozapine, and phenylbutazone..$^{2-7}$ The mechanism of drug induced parotitis is mainly dry mouth as a result of drug hypersensitivity, toxic accumulation or anticholinergic effects. Dryness of the oral mucosa leads to blockage of ducts or lower branches of salivary glands. ${ }^{8}$

As far as we know, there are no reports of development of parotitis after immunosuppressive therapies in English literature, but theoretically, immunosuppressive therapies can increase the risk of viral and bacterial infections in all salivary glands. Apart from a tendency to develop infections due to their treatment induced immunosuppressed state, pemphigus vulgaris patients can also be expected to have an increased risk of parotitis and other salivary gland infections due to various reasons such as oral ulcers, deterioration in oral intake, multiple medications used and other autoimmune diseases that may accompany, although such an association has been reported rarely. ${ }^{9}$ Here, a pemphigus vulgaris patient with enlargement of the parotid glands on both sides is reported and association of parotitis and pemphigus vulgaris is discussed in light of the scarce data in literature.

\section{Case report}

A 51-year-old male patient presented with a twomonths history of widespread ulcers in his mouth. He had been hospitalized and a nasogastric catheter was placed for a while due to his poor oral intake. Personal and family history were unremarkable. Dermatological examination revealed widespread ulcerated areas on buccal mucosa, hard palate, tongue and gums as well as an erythema in the right conjunctiva. Histopathological examination showed suprabasal separation and acantholytic cells and intracellular IgG accumulation was detected in direct immunofluorescence (DIF) analysis. Positive anti-desmoglein 3 antibodies were shown by ELISA whereas antidesmoglein-1 was negative. Based on clinical, histopathological and direct immunofluorescence findings, mucosal dominant pemphigus vulgaris was diagnosed. The patient was started on oral methylprednisolone (48 $\mathrm{mg}$ /day) and methotrexate (15 mg/week). However, methotrexate had to be stopped after a month because of nausea, and mycophenolate mofetil $2 \mathrm{gr} /$ day was initiated. Systemic steroid and mycophenolate mofetil combination was used for an additional month without any improvement. The ongoing severity of oral erosions and deterioration of oral intake necessitated a more effective disease control and the patient was admitted to the dermatology clinic for rituximab treatment. On the following day of $1000 \mathrm{mg}$ rituximab infusion, severe infiltration and swelling of the left preauricular region appeared without any tenderness or pain in jaw movements. The patient was consulted to otorhinolaryngology and the clinical picture was found to be consistent with idiopathic parotitis, and no further investigation was needed (imaging, etc.). No treatment other than hydration was recommended, preauricular swelling regressed spontaneously in a day and the patient was discharged. On his next admission to the clinic for the second infusion of 1000 mg rituximab, oral lesions had significantly improved, however, infiltration and swelling were observed on 




Fig. 1. Infiltration and swelling in the right preauricular region on the face

the other side of the face, in the right preauricular region (Fig. 1). This recurrence of parotitis on the contralateral side regressed in two days with hydration, mouth care and healing of oral lesions with rituximab. Patient's treatment continued with intravenous immunoglobulin, oral and conjunctival lesions healed completely and no recurrence of parotitis was seen in 14-months of follow-up. Written consent was taken from the patient for publication.

\section{Discussion}

Oral mucosa is almost always affected in pemphigus vulgaris patients. Painful erosions and ulcers are the cause of significant impairment in eating and drinking, which then leads to dehydration and malnutrition. Multiple drug exposure, possible accompanying autoimmune diseases, oral ulcers, poor oral intake and risk of superinfection of the oral ulcers are all predisposing factors for development of parotitis and other salivary gland infections in pemphigus patients, however, data about this association is very limited. Two cases of temporary parotitis in pemphigus vulgaris have been reported and parotitis development was considered to be associated with the presence of extensive oral ulcers..$^{9,10}$ There may be different explanations for the scarce data in literature: parotitis may easily be overlooked because of its mild and self-limiting course or it is really an unusual event as current treatment options in pemphigus can prevent its occurrence by providing effective disease control.

In the current patient with pemphigus vulgaris, bacterial or viral infection was not considered as an etiological factor of acute, self-limiting and twosided migratory parotitis because of the otherwise good general health of the patient and the absence of fever and local tenderness. Although he was being treated with systemic steroids and immunosuppressive medications at the time of parotitis development, two-months of treatment is rather short to consider immunosuppression as the principal cause of parotitis. A high incidence of Sjogren's disease has been reported in pemphigus patients ${ }^{11}$, however, significant dominance of Sjogren's and pemphigus association in female patients as well as the chronic course of salivary gland pathologies in Sjogren's disease rather than an acute occurrence as seen in the current patient makes this diagnosis unlikely.

Our patient presented with severe, widespread oral ulcers which significantly disrupted his oral intake, led to weight loss and even resulted in replacement of nasogastric catheter for a short period. First swelling of the parotid gland regressed very rapidly in a day and the second attack on the contralateral side also regressed in a short time without any specific treatment. No recurrence was observed after improvement of oral lesions in the follow-up period despite ongoing steroid therapy. Regarding all these facts in the history and course of the disease, development of acute parotitis in our patient can be explained by dehydration induced mucous plug formation in the parotid ductus and further narrowing of the ductal opening due to widespread inflammation and ulcers in the buccal mucosa. 
In pemphigus vulgaris or patients with impaired oral mucosal integrity and decreased oral intake, unilateral or bilateral swelling of the parotid or other salivary glands should raise the suspicion of salivary gland inflammation. Awareness of such an association is important in terms of rapid diagnosis and treatment and also for prevention of unnecessary advanced tests.

Informed consent: The authors certify that they have obtained all appropriate consent forms from the patient.

Peer-review: Externally peer-reviewed

Authorship contributions:

Conception and design, or analysis and interpretation of data: ECO

Drafting the manuscript or revising the content: $\mathrm{ZO}$

Final approval of the version to be published: DSG

\section{References}

1. Brook I. Diagnosis and management of parotitis. Arch Otolaryngol Head Neck Surg 1992;118:469-71.

2. Mahdiabadi FM, Nikvarz N. Captopril-induced sialadenitis in a patient with end-stage renal disease. J Res Pharm Pract 2016;5:146-8.

3. Brooks KG, Thompson DF. A review and assessment of drug-induced parotitis. Ann Pharmacother 2012;46:1688-99.

4. Kenningham J. An unusual case of postoperative facial swelling. Anaesthesia 2000;55:601-2.

5. Capoccia L, Sbarigia E, Speziale F. Monolateral sialadenitis following iodinated contrast media administration for carotid artery stenting. Vascular 2010;18:34-6.

6. Almeida P de, Gregio A, Brancher JA, et al. Effects of antidepressants and benzodiazepines on stimulated salivary flow rate and biochemistry composition of the saliva. Oral Surg Oral Med Oral Pathol Oral Radiol Endod 2008;106:58-65.

7. Vinasco LG, Bares S, Sandkovsky U. Acute suppurative parotitis caused by Streptococcus pneumoniae in an HIV-infected man. BMJ Case Rep 2015; bcr2014209082

8. Bonnet U, Khalil-Boutros Y. Acute bilateral parotitis occurring during venlafaxine titration in an adolescent female with major depression. Pharmacopsychiatry 2014;47:36-8.

9. Iqbal K, Fassihi H, Setterfield JF, Groves RW. Recurrent acute bilateral facial pain and swelling in a patient with severe recalcitrant pemphigus vulgaris. Clin Exp Dermatol 2011;36:436-7.

10. Frumkin A. Low-dose aurothioglucose in pemphi- gus vulgaris. Isr J Med Sci 1986;22:903-5.

11. Chiu YW, Chen Y da, Hua TC, et al. Comorbid autoimmune diseases in patients with pemphigus: a nationwide case-control study in Taiwan. Eur J Dermatol 2017;27:375-81. 